\title{
Between a Rock and a Hard Place: Treaty- Based Settlement of Terrorism-Related Disputes in the Era of Active United Nations Security Council Involvement
}

\author{
Nathanael Tilahun Ali*
}

\begin{abstract}
The United Nations Security Council has become a crucial actor in international counterterrorism by not only spurring the taking of preventive and suppressive measures against terrorist individuals and groups, but also by taking actions against states that are said to stand in the way. The Security Council's actions against such states invariably arise from accusations by other states, such as accusations of refusal to extradite suspects of terrorism or responsibility for supporting terrorists. Meanwhile, most such issues of dispute are covered under international treaties relating to terrorism, which provide for political (negotiation) and judicial (arbitration and adjudication) mechanisms of dispute settlement. The Security Council's actions against states in connection with terrorism, therefore, involve (explicit or implicit) factual and legal determinations that affect the legal positions of the disputing states under the applicable international treaties relating to terrorism. The point of departure of this paper is that, in this respect, the Security Council effectively becomes an alternative to the treaty-based dispute-settlement mechanisms. The article centrally contends that the Security Council effectively acts as a more attractive alternative to treaty-based dispute-settlement mechanisms for pursuing terrorism-related (legal) disputes between states, without providing a meaningful platform of disputation that is based on equality of the parties. And the Security Council's relative attractiveness, arising from the discursive and legal superiority its decisions enjoy and the relative convenience and expediency with which those decisions are delivered, entails the rendering of resort to treaty-based disputesettlement mechanisms of little legal consequence. The point of concern the article aims to highlight is the lack of platform of disputation some states are faced with, trapped between a hostile Security Council that makes determinations and decisions of legal consequence and an unhelpful treaty-based dispute-settlement mechanism.
\end{abstract}

* PhD Candidate in public international law, Erasmus School of Law. E: ali@law.eur.nl. I would like to thank Prof. Xandra Kramer and Prof Ellen Hey for their valuable comments on an earlier draft of this article. The usual disclaimer applies.
Keywords: Terrorism, inter-state dispute, international treaties, the United Nations Security Council, the International Court of Justice

\section{Introduction}

In December 2009, the United Nations Security Council (hereinafter also 'the Council') imposed financial, travel, and military sanctions and embargoes against the government of Eritrea, claiming that the latter provides support to armed groups that are engaged in 'destabilising activities' in Somalia. ${ }^{1}$ Targeted sanctions were imposed against the political leaders of Eritrea that were implicated in 'harbouring, financing, facilitating, supporting, organizing, training, or inciting individuals or groups to perpetrate acts of violence or terrorist acts against other States or their citizens in the region'2 (emphasis added). The main armed group Eritrea was accused of supporting was an Al-Qaeda affiliate known as Al-Shabaab, which is designated by most neighbouring States and international actors as a terrorist group and spoiler of the Somalia peace process.

The support to terrorism that Eritrea and its political leaders were accused of are covered under different international treaties relating to terrorism, the most obvious example being the 1997 Convention for the Suppression of the Financing of Terrorism (Terrorist Financing Convention), which provides dispute-settlement mechanisms. Most of the international treaties on terrorism, including the Terrorist Financing Convention, were by then not ratified by Eritrea, and in any event the infant Transitional Federal Government (TFG) of Somalia was yet not settled enough to engage in international legal confrontation with Eritrea. Lacking these ingredients, the taking of action through the political channels of the Security Council may appear as the only choice.

Now, consider a hypothetical scenario where Somalia's TFG is fully installed and stable, and both Somalia and Eritrea have become parties to all relevant international

1. SC Res. 1907, 23 December 2009.

2. Id., para. $15(\mathrm{~d})$. 
treaties on terrorism including the Terrorist Financing Convention. Under this scenario, there are two forums through which Somalia can confront Eritrea for its alleged support to the terrorist groups in Somalia: the dispute-settlement mechanisms provided by the Terrorist Financing Convention or the UN Security Council. In this article, an actual instance resembling this hypothetical scenario - a dispute between Libya and three Western states (the US, the UK and France) in connection with the terrorist explosion of a passenger aircraft in Lockerbie, Scotland in 1988 - will be used to showcase and compare the respective roles of the Security Council and the different international treaties on terrorism in addressing inter-state disputes. The core contentions of the article are as follows. The Security Council effectively acts as a more attractive alternative to treaty-based dispute-settlement mechanisms for pursuing terrorism-related (legal) disputes, without providing a meaningful platform for disputation that is based on the equality of the parties. The Security Council's relative attractiveness, arising from the discursive and legal superiority its decisions enjoy and the relative expediency with which those decisions are delivered, in turn renders resort to treaty-based dispute-settlement mechanisms of little legal consequence. As a result, states that do not command sufficient political support at the Security Council are doubly disadvantaged as they face a hostile political mechanism and an unhelpful legal remedy.

The article unfolds as follows. I will first (in Section 2) briefly contrast the Security Council system with the treaty-based dispute-settlement system from the perspective of the characterisation of disputes the two systems entail, specifically with respect to the place of the notion of the 'international community' therein. Flowing from and reinforcing this broad contrast, I will (in Section 3) elucidate certain legal and practical considerations pertaining to the functioning of the two systems in asserting the attractiveness of the Security Council system. Then (in Section 4), I will assess whether an even platform for inter-state disputation could be found within the Security Council itself, to compensate for the curtailed role of the treaty-based dispute-settlement mechanisms. This section looks into the working procedures of the Security Council and its counter-terrorism subsidiary bodies and finds little possibility for entertainment of inter-state disputes in such a manner that outcomes would be based on the weighing of the contesting claims of parties to a dispute. Lastly (in Section 5), I will summarise the main arguments and conclude by briefly highlighting the significance of the central problem in the context of the political climate that followed the terrorist attacks of 11 September 2001.

\section{Terrorism-Related Disputes Under Treaty-Based Dispute-Settlement System and the Security Council System: Elaboration and Contrast}

On the basis of official United Nations records, currently there are eighteen international treaties relating to different acts of terrorism. ${ }^{3}$ All of these treaties contain similar provisions stipulating the dispute-settlement processes to be followed in case of disagreement on their interpretation or application between the states parties. This common provision reads as follows:

Any dispute between two or more States Parties concerning the interpretation or application of this Convention which cannot be settled through negotiation within a reasonable time shall, at the request of one of them, be submitted to arbitration. If, within six months of the date of the request for arbitration, the parties are unable to agree on the organization of the arbitration, any one of those parties may refer the dispute to the International Court of Justice, by application, in conformity with the Statute of the Court. ${ }^{4}$

State parties, therefore, are required to negotiate as a first resort towards settling disputes that arise from the interpretation or application of the treaty. When one of the negotiating parties deems 'reasonable time' has passed while negotiating on the matter without agreement or while making effort to initiate negotiations, that state party is entitled to submit the dispute to arbitration. The parties in dispute must agree on the composition and terms of the arbitration, failing which, subject to the time frame mentioned in the article above, any of the parties would be entitled to submit the matter to the

3. The eighteen treaties are the 1963 Aircraft Convention, 1970 Unlawful Seizure Convention, 1971 Civil Aviation Convention, 1973 Diplomatic Agents Convention, 1979 Hostages Convention, 1980 Nuclear Materials Convention, 1988 Maritime Convention, 1988 Fixed Platform Protocol, 1988 Airport Protocol (extends and supplements the 1971 Civil Aviation Convention), 1991 Plastic Explosives Convention, 1994 UN Personnel Convention, 1997 Terrorist Bombing Convention, 1999 Terrorist Financing Convention, 2005 Nuclear Terrorism Convention, 2005 Protocol to the 1988 Fixed Platform Protocol, 2005 Protocol to the 1988 Maritime Convention, 2010 Protocol to the 1970 Unlawful Seizure Convention and 2010 New Civil Aviation Convention. Generally, visit the UN Counter-Terrorism website, <http://www.un.org/en/terrorism/ instruments.shtml> (last visited 30 Aug. 2013). It is important to note that the international legal framework on terrorism extends beyond these eighteen treaties, incorporating numerous regulatory instruments (such as UN resolutions and international 'standards'). My discussion here is restricted to the eighteen core international treaties as only they contain proper stipulations for dispute-settlement mechanisms.

4. See, e.g., Art. 24 Aircraft Convention of 1963, Art. 12 Unlawful Seizure Convention of 1970, Art. 14 Civil Aviation Convention of 1971, Art. 13. Diplomatic Agents Convention of 1973, Art. 16 Hostages Convention of 1979, Art. 24 Terrorist Financing Convention of 1997 and Art. 20 New Civil Aviation Convention of 2010. 
International Court of Justice (hereinafter 'ICJ', or 'the Court'), which would deliver the final decision on the dispute.

Parallel to the dispute-settlement mechanisms provided by the different treaties on terrorism runs the United Nations Security Council system, the chief international regime for matters of international peace and security. Inter-state disputes relating to terrorism could be dealt with by either the treaty-based dispute-settlement mechanisms or the Security Council system; but the two systems operate in radically differing discursive and legal domains and as a result characterise such disputes differently. An important divergence in the characterisation of disputes between the two systems concerns the determination of the stakeholders involved: treaty-based dispute-settlement mechanisms characterise disputes as essentially matters of contestation between the specific disputing states, while the Security Council system brings the 'international community' to the centre-stage of disputes and characterises inter-state disputes as confrontation between rogue actors and the international community, and not as competing claims between equals. ${ }^{5}$ I will elaborate these two observations below.

\subsection{Characterisation of Disputes Under Treaty-} Based Dispute-Settlement Mechanisms

Although most of the treaties on terrorism characterise their subject matter as being of concern to the international community' in their preambles, this does not translate into operational provisions recognising the international community as a stakeholder or providing it with an entitlement to be involved in the dispute-settlement process. Of course, the operational provisions of treaties would not be expected to bestow concrete rights and obligations on an abstract category such as the international community per se. This, rather, would have taken place by way of assigning roles to international bodies that are bestowed with global responsibilities, hence presumed to represent the interests of the international community as a whole. A primary example of such international institution, in relation to the issue of international peace and security, is the United Nations, and

5. For a critical and historical account of the usage of the indeterminate notion of 'international community', see M. Koskenniemi, '“' International Community" from Dante to Vattel', in V. Chetail and P. Haggenmacher (eds.), Vattel's International Law from a XXI St Century Perspective/Le Droit International de Vattel Vu Du Xle Siècle (2013), at 49-76. Further on the problem of indeterminacy in international law see M. Koskenniemi, From Apology to Utopia: the Structure of International legal Argument (2005) (reissue with epilogue); M. de Hoon, 'Collateral Damage from Criminalizing Aggression? Lawfare Through Aggression Accusations in the Nagorno Karabakh Conflict', 5 European Journal of Legal Studies 1, at 40-61 (2012). For more on 'community interest' in international law, see B. Simma, From Bilateralism to Community Interests in International Law (1994), Collected Courses of the Hague Academy of International Law/Recueil des Cours; S. Villalpando, 'The Legal Dimension of the International Community: How Community Interests are Protected in International Law', 21 European Journal of Int'I Law (EJIL) 2, 387-419 (2010); C. Tomuschat, 'The International Community: Obligations Arising for States Without or Against Their Will', Collected Courses of the Hague Academy of International Law 241 (1993). DOI:10.1163/ej.9780792329541.195-374.2, last accessed 16 August 2013. particularly its Security Council. ${ }^{6}$ A less inclusive form of involving the international community in the resolution of a dispute between two states parties could be the bestowment of a dispute-settlement role on (the assembly of) all state parties to a treaty, particularly when such treaty enjoys (near) universal membership. For example, the Statute of the International Criminal Court provides that disputes relating to the interpretation or application of the treaty 'which is not settled through negotiations within three months of their commencement shall be referred to the Assembly of States Parties" ${ }^{7}$ - a body composed of all the states parties to the Statute as voting participants and some non-state parties as observers. ${ }^{8}$

No such arrangement is included in the treaties on terrorism. The first resort, negotiation, involves only the disputing states parties; ${ }^{9}$ any agreement the disputing states parties reach between themselves would be a legally acceptable conclusion of the dispute, with the caveat, of course, that such agreement has to be consistent with states' obligations under other treaties and general international law. The second and third resorts, arbitration and adjudication by the ICJ, also generally involve only the disputing states parties. Arbitration gives even more autonomy to the disputing parties than the ICJ as its composition and terms of organisation are decided exclusively and on an ad hoc basis by the disputing states parties, thus whether and how interests other than those of the disputing parties would be given consideration in the process is decided exclusively by the disputing parties. Given that arbitration provides the disputing parties with even more autonomy than the ICJ proceeding, the following observation that the inter partes procedure at the ICJ gives little room for consideration of the interests of the international community is a fortiori applicable to arbitration.

As regards the ICJ, Article 62 of the Statute of the Court states that third parties may request permission to intervene in a judicial proceeding only when they claim

6. Member states of the United Nations have conferred upon the Security Council 'the primary responsibility for the maintenance of international peace and security' and have agreed 'that in carrying out its duties under this responsibility the Security Council acts on their behalf' Art. 24(1) UN Charter. It should also be noted that this responsibility is primary, but not exclusive. The General Assembly also bears similar, albeit secondary, responsibility. See Arts. 10-12 UN Charter.

7. Art. 19 the Statute of the International Criminal Court of 17 July 1998.

8. Observer states are those that have signed the Statute of the International Criminal Court or the Final Act of the International Criminal Court of 17 July 1998, Art. 112(1) the Statute of the International Criminal Court.

9. Although exchange between states on a dispute at the United Nations General Assembly had been accepted by the ICJ once as amounting to negotiations, this decision is not widely received by jurists both inside and outside the court. The ICJ itself has added that exchanges conducted at open multilateral forums, although constituting a form of negotiation, are not sufficient to satisfy the legal criteria of negotiation. Whether or not exchanges at multilateral forums constitute negotiation for the purposes of the law is question yet to be conclusively answered. See, J.G. Merills, International Dispute Settlement (2005), at 11-13; dissenting opinions of Judge Spender and Judge Fitzmaurice, in 'South West Africa Cases (Ethiopia v. South Africa; Liberia v. South Africa), Preliminary Objections, Judgment of 21 December 1962', ICJ Report, 1962, p. 319. 
to have 'an interest of a legal nature which may be affected by the decision in the case'. Article 63 of the Statute also gives the right to third states to intervene in a proceeding involving other states if the proceeding relates to 'the construction of a convention' that the third states are parties to. The amended Rules of the Court further allow for an international organisation that is a party to a multilateral convention to 'submit its observations on the particular provisions of the convention the construction of which is in question'. ${ }^{10}$ These provisions, in principle, ${ }^{11}$ open the door to all states and international organisations that are parties to a multilateral treaty to participate in proceedings before the ICJ concerning the interpretation and application of that treaty. ${ }^{12}$ However, under both Articles 62 and 63 of the Statute of the ICJ, the participation of third (states) parties only implies the recognition of the interests of those that are specifically linked to the dispute and not that of the wider 'international community'. In the case of Article 62, the existence of an 'affected interest' is an explicit pre-requisite for intervention (see quote from the article above). In the case of Article 63, only those states that have a contractual link to the subject of dispute are invited to participate. ${ }^{13}$ Even then, there may be differentiation among states parties to a multilateral convention as the ICJ's construction of a multilateral convention binds only those states parties that actually participated in the Court's proceeding as parties. This does not make a meaningful difference in practice, but nevertheless goes to show the exclusively inter partes design of proceedings at the ICJ and the insignificance of external consid-

10. Art. 43(2) Rules of the International Court of Justice, as amended on 29 September 2005.

11. With regard to states parties, the ICJ has on one occasion rejected such intervention, which indicates that 'article 63 does not grant an "automatic" or "absolute" right to intervene.' M.G. Rubio, 'Intervention before the International Court of Justice: the Nicaraguan Intervention in El Salvador/Honduras case', I Mexican Yearbook of International Law, at 165-195, 170 (2001). (This decision of the ICJ has come under criticism, primarily for blurring the distinction between Arts. 62 and 63 of the Statute of the Court). Concerning international organizations, Art. 43(2) of the Rules of the Court makes such participation, and apparently even the privilege of notification provided under Art. 63 of the Statute of the Court, contingent on the discretion of the Court. See, S. Rosenne, Procedure in the International Court: A Commentary on the 1978 Rule of the International Court of Justice (1983), at 99-101.

12. Giorgio Gaja argues that the possibility for third states to submit observations to the ICJ based on Art. 63 should also be interpreted so as to allow states to intervene when a case relates to the interpretation of not only a treaty, but also a general international law rule, and thereby bring in the 'common interests of the international community' in such interpretation. See, G. Gaja, 'A New Way for Submitting Observations on the Construction of Multilateral Treaties to the International Court of Justice', in U. Fastenrath, R. Geiger, D-E. Khan, A. Paulus, S. von Schorlemer and C. Vedder (eds.), From Bilateralism to Community Interest: Essays in Honour of Bruno Simma (2011).

13. The participation of international organizations based on Art. 43 of the Rules of the Court is limited submitting observations and does not include becoming a party to the proceeding. erations such as the interest of the international community. ${ }^{14}$

In sum, the dispute-settlement mechanisms of the treaties on terrorism exclude non-disputing states, and states whose interests are not affected (either independently or through the construction of a multilateral treaty), from the equation of the dispute and aim for the resolution of the dispute as much as possible by the disputing states parties only (negotiation) and, if not, through impartial third parties (arbiters or judges). By so doing, the treaties characterise disputes as matters of contesting claims between equals.

\subsection{Characterisation of Disputes Under the} Security Council System

An intervention of the Security Council in inter-state dispute, in contrast, is presumed to carry the weight of the 'international community', and thereby transform the nature of the dispute into one where one or all sides in the dispute become poised not only against the other state but also against the rest of humanity. In line with this, the Security Council is bestowed with authority to intervene in (almost) any dispute and take (almost) any measure therein. Whether in its capacity as a disputesettlement body according to Chapter VI of the Charter of the United Nations (hereinafter 'the Charter') or in its enforcement powers under Chapter VII, the Security Council acts as a representative of the international community and with an entitlement to intervene in inter-state disputes without the consent of the disputing parties. The Security Council is mandated to take part in the peaceful settlement of disputes - at its own discretion or upon the request of the state parties in a dispute or other states - by way of calling the disputing state parties to resort to peaceful dispute-settlement mechanisms,${ }^{15}$ conducting investigations, ${ }^{16}$ and making recommendations towards such end. ${ }^{17}$ When the Council exercises its enforcement powers, contrary to the norms of treaty law, even non-members of the United Nations would be subjected its authority 'so far as may be necessary for the maintenance of international peace and security' 18

In executing its mandate, the Security Council is not constrained by the specific treaties that may govern the matter in dispute. Granted, when exercising its disputesettlement functions under Chapter VI, Article 36 of the Charter states the Security Council is particularly required to 'take into consideration any procedures for the settlement of the dispute which have already been

14. In the Gabcikovo-Nagymaros case, Judge Weeramantry highlighted that the inter-partes procedure at the ICJ becomes problematic when dealing with international rules affecting 'the greater interests of humanity and planetary welfare'. See Gabcikovo-Nagymaros Project (Hungary/Slovakia), Judgment, ICJ Reports 1997, at 7, Separate Opinion of Vice-President Weeramantry, at 117-118.

15. The Council may call states concerned to settle their disputes through 'negotiation, enquiry, mediation, conciliation, arbitration, judicial settlement, resort to regional agencies or arrangements, or other peaceful means of their own choice', Art. 33(2) UN Charter.

16. Art. 34 UN Charter.

17. Arts. 36-38 UN Charter.

18. Art. 6 UN Charter, see also Art. 32 
adopted by the parties'. Furthermore, the Security Council is expected to encourage states to resolve their disputes using legal and political peaceful dispute-settlement mechanisms, including at regional level ${ }^{19}$ and to take into consideration that 'legal disputes should as a general rule be referred by the parties to the International Court of Justice'. ${ }^{20}$ This appears to create a harmonious link between the dispute-settlement arrangements provided by the specific treaty regimes and the Security Council system. When, for example, disputes relating to terrorist bombing arise between states parties to the 1997 Terrorist Bombing Convention, the Security Council, when seized of the matter, is required to make efforts towards bringing the disputing parties towards negotiation, arbitration, or adjudication by the ICJ, as the Convention stipulates. ${ }^{21}$

This harmony, however, goes only so far. According to Article 37 of the Charter, the Security Council is authorised, when it deems that the dispute is 'likely to endanger the maintenance of international peace and security', to decide 'whether to take action under Article 36 or to recommend such terms of settlement as it may consider appropriate ${ }^{22}$ (emphasis added). Article 36, as mentioned above, stipulates that the Security Council should operate within the legal framework applicable between the parties and as a general rule encourage the parties to prioritise referral of legal disputes to the ICJ. Therefore, following Article 37, the Security Council is at liberty to decide to no longer be bound by the parameters of the legal framework at stake or any agreement between the disputing parties, but only with the 'necessities' of international peace and security. The Security Council enjoys even more discretion once it determines that the situation at hand constitutes 'threat to the peace, breach of the peace, or act of aggression' in accordance with Article 39 of the Charter: the Council can take all necessary measures without being constrained by the specific treaty regime governing the matter of dispute. ${ }^{23}$ This is so widely accepted that the current debate among international law scholars is whether the
Security Council is bound by the most fundamental norms of international law (further discussed below). ${ }^{24}$

The weight of 'international community' that a Security Council intervention entails, and the resulting characterisation of disputes, is better appreciated when contrasted with treaty-based dispute-settlement mechanisms. Take, for example, two state parties to the 1970 Convention for the Suppression of Unlawful Seizure of Aircraft (Hijacking Convention) ${ }^{25}$ entering into a dispute, one requesting for and the other refusing the extradition of suspects of a particular hijacking incident. When the stage of negotiation bears no fruit and the dispute appears before an arbitral or judicial forum, both claims in the dispute (i.e. the request and the refusal of extradition) would be regarded as mere competing claims. This means that there is a possibility for the request of extradition to be found unwarranted (e.g. for lack of jurisdiction) or for the refusal of extradition to be found lawful (e.g. priority of jurisdiction). If the refusal of extradition is found unlawful, it may, nonetheless, be justified by resorting to the grounds that preclude wrongfulness under general international law (say, e.g., necessity, or as countermeasure for the requesting states' previous violation of obligations). Even when the refusal of extradition is found unlawful and unjustifiable, it is framed only as a 'non-fulfillment of treaty obligations'. This framing contrasts with that which would be used in the Security Council system to describe the same scenario. If the Security Council condemns the state party that refused to extradite the suspects, the 'guilty' party would not be a mere violator of treaty obligations, but also a 'threat to international peace and security', a rogue; and such party would be obliged to grant the request of extradition not only out of its treaty obligations, but also out of regard for the interests of the international community, for which the Security Council is regarded a custodian - whether or not the disputing states have given recognition to this custodianship, by way of signing the Charter. ${ }^{26}$
24. The most assertive proposition in this debate regards the Security Council as bound by the Charter itself, peremptory norms of international law, fundamental human rights, and also general international law. While the restrictive proposition regards only the Charter and peremptory norms of international law applicable. See, e.g., E. de Wet, The Charter VII Powers of the United Nations Security Council (2004); D. Akande, 'The International Court of Justice and the Security Council: Is there Room for Judicial Control of Decisions of the Political Organs of the United Nations?', 46 Int'l. \& Comp. L. Q. (1997) 309; J. E. Alvarez, 'Judging the Security Council', 90 Am. J. Int'I. L. (1996S) 1; V. Gowlland-Debbas, 'The Relationship between the International Court of Justice and the Security Council in the Light of the Lockerbie Case', $88 \mathrm{Am}$. J. Int'I. L. (1994) 643; 'Is the Security Council bound by Human Rights Law?', 103 Proceedings of the Annual Meeting-American Society of International Law, 2009; K. Roberts, 'Second-Guessing the Security Council: The International Court of Justice and its Powers of Judicial Review', 7 Pace Int'I. L. Rev. (1995) 281.

25. Adopted on 16 December 1970.

26. Combined reading of Arts. 2(6) and 32 of the UN Charter. 


\section{The Weakening of Treaty- Based Dispute Settlement on Terrorism: the Case of Libya, 1992}

A scenario resembling the above hijacking example has in fact taken place in connection with the explosions of the American Pam Am airline's flight 103 in Lockerbie, Scotland, in 1988, and that of the French airliner UTA flight 772 in Niger in 1989. A large number of American, British and French citizens were among those killed in the explosions of the two flights; and these three states conducted investigations, the results of which implicated Libyan state operatives in both incidents. In particular, two Libyan nationals - Abdelbaset al-Megrahi and Lamin Khalifah Fhimah - were sought by the US and the UK for criminal prosecution. The US and the UK then demanded that 'Libya must:

- [Demand 1] Surrender for trial all those charged with the crime; and accept responsibility for the actions of Libyan officials;

- [Demand 2] Disclose all it knows of this crime, including the names of all those responsible, and allow full access to all witnesses, documents and other material evidence, including all the remaining timers;

- [Demand 3] Pay appropriate compensation. ${ }^{27}$

The explosions of both Pan Am 103 and UTA 772 were said to have occurred as a result of the explosive materials placed in the aircrafts by operatives linked to and directly coordinated by Libyan intelligence officials. Accordingly, both incidents under the stipulations of the 1971 Convention for the Suppression of Unlawful Acts against the Safety of Civil Aviation (the Montreal Convention), ${ }^{28}$ Article 1 of which states:

Any person commits an offence if he unlawfully and intentionally:

(b) destroys an aircraft in service or causes damage to such an aircraft which renders it incapable of flight or which is likely to endanger its safety in flight; or

27. Letter dated 20 December 1991 from the Permanent Representative of the United States of America to the United Nations addressed to the Secretary General, A/46/826, S/23308. France has also made demands relating to Libya's cooperation for the criminal proceedings being undertaken in France, and the Security Council has also endorsed those demands along with those of the US and the UK. The focus here is on the demands by the US and the UK as those contained specific requests (France generally requested that Libya cooperate by facilitating contacts, handing over evidence etc.), and because those were the ones that eventually led to a contentious case before the ICJ, as will be discussed below.

28. Adopted at Montreal, on 23 September 1971. (c) places or causes to be placed on an aircraft in service, by any means whatsoever, a device or substance which is likely to destroy that aircraft, or to cause damage to it which renders it incapable of flight, or to cause damage to it which is likely to endanger its safety in flight;

When Libya refused to immediately comply with their demands, the US, the UK and France took the matter to the Security Council, which endorsed their demands and adopted a non-Chapter VII (thus not binding) resolution - Resolution 731 - requesting Libya 'immediately to provide a full and effective response to those requests' ${ }^{29}$ The resolution stayed clear of any mention of the Montreal Convention and framed the issue entirely in terms of the policy goal of the 'elimination of international terrorism'. ${ }^{30}$ The message was that the matter was not of 'mere' inter-state dispute but one of interest to the international community, and hence not to be confined within the bounds of whatever legal scheme was applicable between the states involved.

Libya resorted to the ICJ and instituted separate but identical proceedings against the $\mathrm{US}^{31}$ and the $\mathrm{UK}^{32}$ (the 'Lockerbie cases') in which it specifically protested the request for the extradition of its two nationals (demand 1, see above) as unlawful. The Lockerbie cases have been the subject of intense debate in international legal scholarship, ${ }^{33}$ and so I do not intend to rehearse or engage in this debate here; it suffices to highlight that Libya's fundamental premise was that its dispute with the Respondents on the extradition of the suspects falls under the Montreal Convention, which provides for the

29. Para. 3, SC Res. 731, 21 January 1992.

30. Preamble and para. 3, SC Res. 731, 21 January 1992.

31. Questions of Interpretation and Application of the 1971 Montreal Convention Arising from the Aerial Incident at Lockerbie (Libyan Arab Jamahiriya v. United States), Application Instituting Proceedings, 3 March 1992.

32. Questions of Interpretation and Application of the 1971 Montreal Convention Arising from the Aerial Incident at Lockerbie (Libyan Arab Jamahiriya v. United Kingdom), Application Instituting Proceedings, 3 March 1992.

33. See, e.g., D.D'Angelo, 'The "Check" on International Peace and Security Maintenance: The International Court of Justice and Judicial Review of Security Council Resolutions', 23 Suffolk Transnat'l L. Rev. (2000), at 561; E. Zubel. 'The Lockerbie Controversy: Tension Between the International Court of Justice and the Security Council', 5 Annual Survey of International \& Comparative Law 1 (2010): Art. 10; W.M. Reisman, 'The Constitutional Crisis in the United Nations', Yale Faculty Scholarship Series, Paper 866, available at < http:// digitalcommons.law.yale .edu/fss_papers/866 > (last visited 25 Aug. 2013). 
settlement of disputes ultimately through the ICJ. ${ }^{34}$ Substantively, Libya argued, correctly, that there is no obligation to extradite suspects (and certainly not one's own nationals) under international law, unless such is provided for through treaty. Libya did not have an extradition treaty with either of the requesting states, and the Montreal Convention does not oblige states in the territory of which the alleged offender is found to extradite the suspect. The Montreal Convention only requires that should such state not extradite the suspect, it must then 'submit the case to its competent authorities for the purpose of prosecution' (the principle of aut dedere aut judicare). ${ }^{35}$ Additionally, Libya protested that granting demand 3 (paying compensation) jeopardises its legal position as that would imply acceptance of responsibility for the offences, which Libya denied.

By instituting proceedings at the ICJ, Libya set in motion the dispute-settlement mechanism provided by the Montreal Convention on an apparent path of collision with the process started at the Security Council. The US and the UK challenged the jurisdiction of the ICJ on the dispute claiming, inter alia, that the matter was not essentially about the interpretation or application of Montreal Convention, but rather one about the protection of the interests of the international community. Their argument was not that the facts of the case did not fit within the stipulations of Montreal Convention, but rather to say, as the US put it, that the Convention is not relevant 'because it was not a question of "bilateral differences" but one of "a threat to international peace and security resulting from State-sponsored terrorism"" ${ }^{36}$ The ICJ rejected this argument based on the ground that the exercise of power by the Security Council does not exclude the concurrent exercise of jurisdiction by the Court on a similar matter. ${ }^{37}$ Indeed, it is widely accepted that the ICJ and the Security Council

34. Art. 14 Montreal Convention. Libya had exhausted, as ICJ confirmed, the options of negotiation and arbitration. Gowlland-Debbas reports, 'Libya addressed several communications to the Security Council requesting the cooperation of the United Kingdom and the United States in its investigations and declaring its willingness to negotiate.' See UN Docs. S/23221, S/23226 (1991), and S/23396, S/23416 (1992). Its request for arbitration is dated 18 January 1992. It also expressed its willingness to cooperate with the Secretary-General and proposed, on various occasions, that the two suspects be surrendered to the United Nations, the Arab League, the judicial authorities of a third country or an international judicial or arbitral body. See Report of the Secretary General pursuant to paragraph 4 of Security Council Resolution 731 (1992), UN Doc. S/23574 (1992); Further Report by the Secretary-General pursuant to paragraph 4 of Security Council Resolution 731 (1992) UN Doc. S/23672 1992)'. V. Gowlland-Debbas, 'The Relationship between the International Court of Justice and the Security Council in the Light of the Lockerbie Case', 88 Am. J. Int'l L. 44 (October 1994), at 643. See also, E. Zubel. 'The Lockerbie Controversy: Tension between the International Court of Justice and the Security Council', 5 Annual Survey of International \& Comparative Law 1 (2010): Art. 10.

35. Art. 7 Montreal Convention, 1971. See further, M.C. Bassiouni \& E.M. Wise, Aut Dedere Aut Judicare: The Duty to Extradite or Prosecute in International Law (1995)

36. Questions of Interpretation and Application of the 1971 Montreal Convention arising from the Aerial Incident at Lockerbie (Libyan Arab Jamahiriya v. United States of America), Preliminary Objections, Judgment, ICJ Reports 1998, at 115, para. 23

37. Id., paras. 27-28. could assume concurrent jurisdiction; while the Charter explicitly bars the General Assembly from exercising its powers on matters that the Security Council is seized upon, no similar inhibition was included in the Charter with regard to the ICJ. ${ }^{38}$ So, the judicial dispute-settlement venue provided by the treaties on terrorism, i.e. the ICJ, would not be brought to a halt by the mere fact that the Security Council is seized of the same matter. How, then, does the increased intervention of the Security Council on terrorism disputes weaken the treaty-based dispute-settlement mechanisms? The answer to this question consists of legal and factual considerations that in combination render resort to treaty-based dispute settlement of little consequence, while increasing the appeal of resort to the Security Council venue: the suspension of treaty rights through binding Security Council resolutions, the unlikelihood and limited consequence of a review of Security Council's determinations, and the significant disparity in expediency between the two systems. Not least, these legal and practical advantages are also accompanied by strong counterterrorism policy arguments. I will use again the Lockerbie cases to illustrate these points.

\subsection{Security Council Resolutions and the Suspension of Treaty Rights}

Anticipating that military action or binding Security Council resolutions would be taken by the US and the UK in pursuance of their demands, Libya requested the Court to indicate 'provisional measures' to protect its claimed rights under the Montreal Convention. Of specific relevance to the measures of the Security Council, Libya requested the Court

to ensure that no steps are taken that would prejudice in any way the rights of Libya with respect to the legal proceedings that are the subject of Libya's Application. ${ }^{39}$

As anticipated, the Security Council adopted a binding resolution, Resolution $748,{ }^{40}$ immediately after Libya submitted its request for provisional measures. Resolution 748 demanded that Libya 'comply without any further delay' with the request under Resolution 731 , by implication the original demands forwarded by the US, the UK, and France. It also imposed a range of military, diplomatic, and financial sanctions on Libya, which all member states of the United Nations were then obliged

38. Certain expenses of the United Nations (Art. 17, para. 2, of the Charter), Advisory Opinion of 20 July 1962: ICJ Reports 1962, at I5I.

39. Para. 7(b), Request for the Indication of Provisional Measures of Protection Submitted by the Government of the Socialist People's Libyan Arab Jamahiriya, 3 March 1992.

40. Adopted on 31 March 1992 
to enforce. ${ }^{41}$ What is most important here is not the content of the sanctions, but the fact that, through the use of a Security Council resolution, Libya was put under legal obligation to concede to the original demands of the requesting states.

The ICJ is empowered, under Article 41 of its Statute, to indicate provisional measures if it deems the later necessary 'to preserve the respective rights of either party' in a dispute (emphasis added). ${ }^{42}$ The Court, however, did not grant the provisional measures that Libya requested based on the reasoning that the rights claimed by Libya that were meant to be protected had vanished prima facie ${ }^{43}$ through the coming into effect of the binding Security Council resolution, Resolution 748. Libya's claimed rights not to extradite its two nationals had originated from the Montreal Convention, with which Resolution 748 came in direct contradiction by instructing Libya to extradite the two suspects. The Court reasoned, based on Article 103 of the Charter, which provides that member states' obligations arising under the Charter prevail over those arising from any other international treaty, Resolution 748 prima facie prevails over the provisions of the Montreal Convention. As a result, Libya's claimed rights under the Montreal Convention were rendered prima facie non-existent since the coming into effect of Resolution 748, and so the Court rejected Libya's request for provisional measures based on the reasoning that there is no apparent 'right' to be protected. As pointed out above, states are not barred from resorting to the treaty-based dispute-settlement mechanisms; however, their rights that the treaty-based dispute-settlement mechanisms are built to protect effectively vanish (provisionally) once the Security Council adopts binding measure that takes away those rights.

\subsection{Unlikelihood and Limited Consequence of}

Review of Security Council's Determinations One may still contend that in this particular case, after the merits stage, the ICJ could find the measures of the Security Council unlawful and uphold Libya's rights under the Montreal Convention. This contention is, however, highly theoretical. The possibility of an ICJ 'judicial review' of the measures of the Security Council has been a subject of intense legal debate, and I do not intend to engage that debate in detail here. What one

41. The sanctions include the denial of permission to any aircraft to take off from, land in or overfly their territory if it is destined to land in or has taken off from the territory of Libya', prohibition of any form of technical aviation cooperation, prohibition of transfer by any means of 'arms and related materials of all types' to Libya, prohibition of technical military cooperation, the reduction of 'the number and level of staff at Libyan diplomatic missions and consular posts', restriction or control of such staff, closure of Libyan Air Lines offices, and expulsion or denial of entry of Libyan nationals involved in terrorist activities.

42. Art. 41(1) Statute of the International Court of Justice, 1945.

43. The non-existence of Libya's rights under the Montreal Convention is prima facie in that definitive decision could only be reached after examination during the merits stage of the proceeding. The merits stage of the proceeding, however, never came to conclusion as the case was terminated in 2003 at the request of the disputing parties. International Court of Justice, press release 2003/29, 10 September 2003. Available at <http://www.icj-cij.org/docket/index .php? pr=168\& code=lus\&p1= $3 \& p 2=3 \& p 3=6 \&$ case $=89 \& k=82>($ last visited 20 Aug. 2013). can safely conclude from this debate, however, is that although the possibility for the ICJ to review the legality of Security Council's measures could exist, the basis of such review is a narrow set of legal grounds. The legal grounds that most authors agree on are the purposes and objects of the $\mathrm{UN},{ }^{44}$ procedural requirements for decision making, and the most fundamental norms of international law (such as fundamental human rights), including peremptory norms of international law (such as the prohibition of genocide). ${ }^{45}$ As regards general international law being a basis for reviewing the legality of Security Council measures, the most generous conclusion is only that there is no consensus yet.

Even assuming that the ICJ could review the legality of Security Council measures on the basis of the abovementioned grounds, such review would almost certainly fall short of reinstating parties in a dispute to the original legal positions in relation to the dispute under the applicable treaty on terrorism. Taking the example at hand, the effect of Resolution 748 as regards superseding Libya's claims could only be declared unlawful if the resolution was adopted by the Security Council in violation of the procedural (decision making) or substantive (purpose and object of the UN, the most fundamental norms of international law) limits on its power. If the Security Council acts within the letters of the Charter (which is presumed to be the case, prima facie, according to ICJ jurisprudence ${ }^{46}$ ) and does not take measures so extreme that they violate most fundamental norms of international law, the rights of Libya under the Montreal Convention remain superseded.

More importantly, even if a review of Security Council's resolutions takes place based on the above standards, important legal determinations contained in such resolutions may not be affected. Security Council resolutions, while operating within the broader political mandate of the 'maintenance of international peace and security', often make (implicit or explicit) factual and/ or legal determinations. Such determinations affect the legal positions of the disputing parties under the specific treaty governing the subject of the dispute between the

44. Art. 2(4) UN Charter.

45. See, e.g., V. Gowlland-Debbas, 'Security Council Enforcement Action and Issues of State Responsibility', 43 Int'l \& Comp. L.Q. 55, at 659-661 (1994); D. Akande, 'Old Questions and New Challenges for the UN Security System: The Role of the Security Council in the Light of the Charter's Reform', 5 Journal of Int'l Law \& Policy 2 (2007); A. Orakhelashvili, 'The Impact of Peremptory Norms on the Interpretation and Application of United Nations Security Council Resolutions', 16 EJIL 1, at 59-88 (2005)

46. And hence the burden of proof for a contrary allegation rests on the one making it. See, Certain expenses of the United Nations (Art. 17, para. 2, of the Charter), Advisory Opinion of 20 July 1962: ICJ Reports 1962, p. I5I, at 168 . 
parties. ${ }^{47}$ Often, such factual and/or legal determinations have an effect such that one side of the dispute would effectively be deprived of a better legal position that it would have enjoyed under the specific treaty governing the subject matter of the dispute. And even if the ICJ were to review such a Security Council resolution, factual and/or legal determinations of the Council that only affect the legal positions of the parties under the otherwise applicable specific treaty would almost certainly pass unchallenged.

Assume, for example, that Resolution 748, after ordering Libya to comply with demand 1 (extradite the two suspects), contained sanction measures that violate the peremptory norms against genocide ${ }^{48}$ or the Charter principle of the inherent right of states to self-defence. The Court, if it would review the resolution, could only 'outlaw' the sanctions part of the resolution for violation of a fundamental norm of international law or a Charter principle, while leaving the order to comply with demand 1 intact. This is because the order to comply with demand 1 only violates Libya's rights not to extradite the suspects arising from the Montreal Convention. The Montreal Convention is not a fundamental norm of international law, but an ordinary treaty that is subject to the supremacy of Security Council resolutions based on Article 103 of the Charter. Hence, even if we assume the ICJ would undertake a review of Security Council resolutions, such review would not affect parts of the resolutions that contain determinations bearing only on the legal positions of the disputing parties vis-à-vis the otherwise applicable terrorism treaty.

\subsection{The Convenience and Expediency of} Decision Making by the Security Council

Equally, or even more important than the above two legal challenges, the disparity between the Security Council system and the treaty-based dispute-settlement process, particularly the ICJ venue, in terms of expediency entails significant practical disadvantage for states relying on the treaty-based alternative to solve disputes relating to terrorism. The Security Council system is far more expedited a process than that of the ICJ, for the

47. D. Bowett, 'The Impact of Security Council Decisions on Dispute Settlement Procedures', 5 EJIL, at 89-101 (1994). Another prominent commentator, Vera Gowlland-Debbas, suggests, when discussing the law on state responsibility in particular, that concerning the ICJ and the Security Council systems, 'we can no longer speak of two alternative methods of dispute settlement, the one political and the other legal, but of two alternative processes available to states within the legal framework of state responsibility: the distinction between the function of the Court and that of the Council becomes the distinction between judicial settlement procedures in disputes concerning responsibility and institutionalized countermeasures or sanction', V. Gowlland-Debbas, 'The Relationship Between the International Court of Justice and the Security Council in the Light of the Lockerbie Case', $88 \mathrm{Am}$. J. of Int'l L. 4 at 643 (October 1994)

48. Such scenario was actually contemplated before the ICJ in the Bosnia \& Herzegovina case when a dissenting opinion held that a Security Council resolution in question, by imposing an arms embargo, might have exposed 'Bosnian Muslims to genocidal activity'. Judge Lauterpacht in Application of the Convention on the Prevention and Punishment of the Crime of Genocide (Bosnia \& Herzegovina v. Serbia \& Montenegro), Provisional Measures, 1993 ICJ Reports, at 325 obvious reasons of procedural fairness and high degree of formality attached to judicial proceedings. Again, the Lockerbie cases illustrate this disparity aptly. Libya submitted its Applications and Request for Provisional Measures to the ICJ based on the Montreal Convention in March 1992. The Court decided on the request for Provisional Measures about a month later, but it took six years before the Court passed a judgment on the preliminary objections to its jurisdiction. When the parties decided to withdraw the case in September 2003, i.e. eleven years after the initiation of the proceedings, the Court had not yet completed the merits stage. By that time, the Court had received the Counter-memorial from the Respondents, Libya's Rebuttal, and Rejoinders from the Respondents. That meant only the completion of the written stages of the proceedings; the oral hearings and the Court's own deliberations would have taken another few years had the case not been withdrawn. Against this time-frame comes the swift decision making of the Security Council: in this particular case, the binding resolution, Resolution 748 , was taken only a little more than a month after the adoption of the preceding resolution, Resolution 731, and even less than a month after Libya's institution of the proceedings at the ICJ (Resolution 748 was taken in haste as a response to Libya's legal action). Therefore, even if some remedy would be expected of adjudication through the ICJ (through the above-discussed narrow possibility), such remedy comes too late. Although not a formal barrier, this disparity in expediency has the practical effect of discouraging resort to treaty-based dispute-settlement procedures, particularly when states become convinced that the Security Council venue would be malleable to their desires.

Based on the above discussed legal and practical considerations, the Security Council platform appeals as a more efficient forum and likely to be the preferred forum for pursuing inter-state disputes relating to terrorism - provided that at least one of the disputing parties sees a fair chance of succeeding through the Security Council system or just an advantage in overshadowing the treaty-based dispute-settlement process. What is problematic is not the construal of some incidents that fall under the different treaties on terrorism as threats to international peace and security, but rather the possibility that virtually all incidents that fall under any of the treaties on terrorism could be so construed. This possibility - inferred through factual and legal reasoning appears to defeat the very purpose of devising the dispute-settlement provisions of treaties on terrorism. Treaties on terrorism deal with instances of violence - be it bombing, hijacking, hostage taking, or their financial and support system - that are factually within the domain of 'peace and security'. It is difficult to imagine offences that fit the descriptions of the different terrorism treaties that would not easily lend themselves to portrayal as issues of 'international peace and security'; therefore, almost all of the offences covered by the different treaties on terrorism in theory invite Security Council's intervention. Legally, the Security Council 
has already designated international terrorism as a threat to international peace and security and has a corresponding ongoing agenda item. ${ }^{49}$ Therefore, when the Security Council deals with a particular dispute relating to terrorism, it would not appear to be abusing its powers to single out and deal with an incident that manifestly fails to constitute an international threat; rather, the Council appears as merely dealing with another instance that falls under an ongoing (broader) agenda item. In other words, it is easier for states, particularly those that wield strong influence on the functioning of the Security Council, to mobilise the later for action against their opponents in a dispute relating to terrorism by framing the scenario as another manifestation of the 'grave threat of international terrorism'.

This appeal of expedient victory at the Security Council venue, taken together with the Council's increased concern for issues of terrorism in the post-9/11 world, entails a weakening effect on the treaty-based disputesettlement mechanisms. One author has predicted the unfolding of this tendency when the Lockerbie cases were withdrawn from the ICJ after Libya conceded to the demands of the US, the UK and France under the force of Security Council's sanctions: 'Security Council Resolutions 731 and $748[\ldots]$ set a precedent for the avoidance of having to negotiate the jurisdictional quagmire posited by the Montreal Convention' ${ }^{50}$ - and this conclusion holds true with respect to the entire dispute-settlement arrangement of any other international treaty on terrorism.

But, of course, an increased involvement of the Security Council in disputes relating to terrorism and the resulting weakening of treaty-based dispute-settlement mechanisms is not necessarily bad news for everyone. There are strong policy reasons advanced in criticising the treaty-based dispute-settlement mechanisms and upholding the increased intervention of the Security Council in disputes relating to terrorism as only appropriate in the face of increasing global security imperatives. I will discuss the major policy considerations advanced in this line of argument below.

\subsection{Policy Arguments for Security Council Intervention}

Practically, the slow and cumbersome dispute-settlement processes provided under the treaties on terrorism are simply unhelpful when swift response to disputes is the only sound policy: recall the dramatic disparity in length of time it took for the ICJ and the Security Council to deal with the Lockerbie incident, and compare the legal process at the ICJ where a state has to

49. The issue of international terrorism has since become one of the few institutionalized permanent items on the agenda of the Council. For example, there are only two other ad-hoc committees of general mandate under the Security Council besides the CTC - the Committee on Nuclear, Chemical and Biological Weapons (Res. 1540), and the General Council of the UN Compensation Commission (Res. 692).

50. J.A. Frank, 'A Return to Lockerbie and the Montreal Convention in the Wake of the September 11th Terrorist Attacks: Ramifications of Past Security Council and International Court of Justice Action', 30 Denver Journal of International Law and Policy 4, at 532-548, 546 (2003). substantiate its claims with evidence to the political process at the Security Council where evidence does not necessarily play a (decisive) role in winning-over votes. Where the speedy completion of the Somalia peace process is at stake, for example, it would be unrealistic to demand that the concerned states go through years of legal battle to establish Eritrea's connection to the terrorist groups spoiling the peace process before taking meaningful action against it. In this case, the framing of disputes relating to terrorism as questions of international peace and security, and hence the taking of measures through the Security Council, would appear more helpful, even when such measures would imply the abrogation of certain rights that Eritrea might enjoy under an otherwise applicable treaty regime.

A related frequently raised practical consideration is that state involvement with or support to terrorism is extremely difficult to prove before a court of law as it is an extremely intricate business. Security imperatives may demand action even in the absence of evidence that would be sufficient and admissible before a court of law; the later requires a high threshold of evidence and observance of certain rules regarding the way such evidence is gathered. In this light, the treaty-based dispute settlement could be said to work to the advantage of state parties that indirectly violate the treaties but deny culpability. It is only sound, so this argument goes, that the Security Council system be utilised to deny impunity to such states. Following the assassination attempt on President Hosni Mubarak during a visit in Addis Ababa in 1995, Ethiopian (and Egyptian) authorities accused Sudan of sheltering the three suspects and demanded their extradition. When Sudan denied any involvement in the attack and any knowledge about the whereabouts of the suspects, Ethiopia brought the matter to the Security Council which ordered Sudan to immediately extradite the suspects to Ethiopia and imposed sanctions on Sudan. ${ }^{51}$ By resorting to the Security Council, Ethiopia circumvented the burden of having to prove the presence of the suspects in the territory of Sudan before the ICJ, which would have been required had the matter been pursued based on the 1973 Convention on the Prevention and Punishment of Crimes Against Internationally Protected Persons including Diplomatic Agents, to which Sudan was a party by then.

In addition to these practical aspects, there is also a legal hurdle that the Security Council venue helps overcome in relation with disputes on terrorism. This is the case where states are said to 'abuse' their rights under the treaty regimes to openly harbour and protect suspects of terrorism. This was precisely what was at stake in the Lockerbie instance. The US, the UK and France were not satisfied with Libya's offer that it prosecute the suspects in its own courts. They believed the government of Libya itself was complicit in the crimes and therefore the suspects would not be appropriately prosecuted. As was mentioned earlier, the Montreal Convention provided that states in whose territory the suspect is found

51. SC Res. 1044 of 31 January 1996 and Res. 1054 of 26 April 1996 
may refuse to extradite, in which case such state is under obligation to - note this - 'submit the case to its competent authorities for the purpose of prosecution 52 (emphasis added). The obligation is not to automatically prosecute; the said authorities would have to determine (depending on the margin of discretion their laws grant them) whether and with what offence to prosecute the suspect. Furthermore, practically speaking, even if Libya proceeded to prosecute the suspects, the US et al. would not be convinced that 'justice would be served' as they may not trust Libya's justice system. In the face of the problem of 'state-sponsors' providing refuge to terrorist under the cover of treaty-based rights, so the argument goes, it is only sensible that such matters be dealt with through the Security Council system.

In sum, the active involvement of the Security Council in disputes relating to terrorism is being applauded, particularly by states that wield influence on the functioning of the Council, for the policy reasons of timely and expedited response and the prevention of abuse of the treaty regimes by so called state-sponsors of terrorism. The supremacy of the Security Council's binding resolutions over treaty obligations ${ }^{53}$ provides a strong reason and argument for a disputing state party that secures a more favourable outcome through the Council to frustrate treaty-based dispute-settlement mechanisms that may compromise the legal or material advantages it has obtained through the Council.

In this light, a disputing state party that would bear an unfavourable outcome from the Security Council is in a (potentially) devastating position as loss at the Security Council spells loss or outright rejection at treaty-based dispute-settlement mechanisms. It may therefore be worthwhile to assess whether states could meaningfully utilise the Security Council and its subsidiary bodies dealing with terrorism as balanced platforms of disputation where the outcome is contingent on the weighing of the contesting claims of all sides. The next section will show that such possibility is highly unlikely.

\section{Inter-state Disputation Within the Security Council System}

\subsection{Disputation Within the Security Council}

The Security Council appears to provide a platform for inter-state disputation, but there is less than meets the eye. True, the working procedures of the Security Council allow for the hearing of all parties to a dispute, allowing them to propose agenda items or draft resolutions and participate in the proceedings of the

52. Art. 7 Montreal Convention, 1971

53. According to Art. 103 of the UN Charter.
Council. ${ }^{54}$ And any state, regardless of its membership of the UN, would be invited to participate in the meetings of the Security Council, without vote, 'if it is a party to a dispute under consideration by the Council'55; and any member state of the UN would likewise be invited 'if it brings a matter to the attention of the Council', regardless of being a party to the dispute. ${ }^{56}$ Even when not invited, states can forward their views and claims to the Security Council through the Secretariat or the General Assembly. ${ }^{57}$

However, these possibilities at the Security Council hardly provide a balanced platform where the outcome would depend on the relative weight of the competing arguments. At least two main reasons support this contention: the lack of evidentiary or legal standards constraining the Security Council's discretion, and the entrenchment of fixed political interests through the veto power of the five Permanent Members of the Council (the P5). The first issue has more impact after the Security Council determines that a dispute is likely to give rise to or already constitutes a threat to international peace and security, as it would then be authorised to impose any terms of settlement 'as it may consider appropriate $^{58}$ or coercive enforcement measures under Chapter VII of the Charter. The Security Council is bestowed with a wide margin of discretion in making these determinations, and taking subsequent measures. There are no compulsory evidentiary or legal considerations that the Security Council has to fulfil in order to reach its decisions: the only determinant factor is the agreement of sufficient number of members of the Council (and non-objection of any of the P5), which is essentially a matter of political negotiation.

The Security Council is not required to substantiate its decision with (a degree of) evidence. When the Security Council endorsed the accusations of the US, the UK and France against Libya through Resolution 731, for example, it neither demanded the presentation of evidence, nor presented its decision as being backed by the weight of evidence. The same is true as regards legal

54. States can bring an issue to the attention of the Security Council through the Secretariat (Rule 6 Provisional Rules of Procedure of the Security Council), through the General Assembly (Rule 3), or directly when invited by the Council to participate in a meeting (Rule 38). Note that the permanent members of the Security Council cannot exercise their veto power for procedural matters, i.e., an agenda cannot be vetoed away from consideration by the Council, Art. 27(2) UN Charter.

55. Art. 32 UN Charter.

56. Rule 37, Provisional Rules of Procedure of the Security Council. Based on its power to determine its rules of procedure, the Security Council has restricted the participation of non-Council members to only formal meetings: such states would not be allowed to participate or would participate only upon invitation in the 'informal' consultations and dialogues on the matter. The 'private-public' distinction regarding the meetings of the Council should not be conflated with the 'formal-informal' distinction: the former distinction is based on whether the meeting or records of it are publicly accessible, while the later distinction is based on the presence or absence of official records and formalized procedures during the meeting. A private meeting of the Council (closed to the public) could, therefore, still be a formal meeting. See, Note by the President of the Security Council, S/2010/507.

57. Rules 3 and 6 , Provisional Rules of Procedure of the Security Council.

58. Art. 37(2) UN Charter. 
standards. It does not (should not) necessarily matter to the Security Council which party to the dispute has (claimed) what legal rights (except, arguably, for those that would be inferred from the purpose and objects of the UN, and the fundamental norms of international law, as discussed earlier). Or, to put it more appropriately, disputing parties have no entitlement to have their (claimed) legal rights observed or even given due consideration. This does not mean these states do not have the right to present those claims; it rather means there is no requirement in its rules of procedure that forces the Security Council to give due consideration to those claims or motivate its decisions in light of those claims. The issue here is not that the Security Council operates on political considerations instead of legal - if such distinction could ever be maintained - but that there are no mechanisms in the decision-making process of the Security Council that disputing parties could utilise to automatically trigger procedural or substantive considerations attuned to their legal claims.

The fact that the decision of the Security Council could be swayed to whichever way one manages to pull the requisite political consensus, however, does not mean outcome is always contingent upon the balance of persuasion. To the contrary, due to the factor of the veto power of the P5, outcome is highly predetermined: outcome that any of the P5 would be oppose to will not materialise. Precisely for this reason, disputing states resort to the Security Council only when they desire to simply register their positions (thus not expecting outcome) or when they actually anticipate victory. There could be exceptions, there could be change of positions once the Security Council proceedings are under way, but as a matter of general practice, there are hardly inbetween cases where disputing parties submit their cases before the Security Council and eagerly await for an unpredictable outcome, or an outcome contingent on the weight of their arguments. Such is a manifestation of 'false contingency' - to borrow the term that Susan Marks uses in a Marxian critique of international legal scholarship $^{59}$ - that processes appear neutral and their outcomes seem contingent on the relative weight of competing arguments, but in fact yield consistently predetermined outcomes. While the subsidiary bodies of the Security Council do not pretend to entertain questions other than those of enforcement (as will be shown below), the process at the Security Council allows for the hard questions to float, but the answers to them are predetermined, or more precisely, determined not by 'the weight of the better argument' but by their conformity with the desires of the P5.

\subsection{The Subsidiary Bodies of the Security Council}

The subsidiary bodies of the Security Council that deal with terrorism are the Counter Terrorism Committee (CTC), the different Sanctions Committees, and the

59. S. Marks, 'False contingency', 62 Current Legal Problems 1, at 1-21 (2009). expert bodies working under both. The mandates of these subsidiary bodies are 'managerial' by design: they subsume the premise that what constitutes a problem is already decided (elsewhere) and the task at hand is the effective management of the problem. ${ }^{60}$ The subsidiary bodies come into existence to implement decisions of the Security Council, thus including the (implicit) determination of rights and obligations constituting the core of the dispute, as discussed earlier. This exclusive devotion to matters of execution is best reflected in the working of the Sanctions Committees, which are established to oversee the effective implementation of the enforcement measures on whoever is regarded by the Security Council as the 'guilty party' in a dispute. Along with the imposition of the sanctions on Libya through Resolution 748 , such committee was established to receive and examine state reports on compliance, to track and disseminate information on violation of the sanctions, to 'recommend appropriate measures in response to [such] violations'. ${ }^{61}$ The Sanctions Committee on Libya, as all other sanctions committees, may decide on Libya's or other actor's specific request for leniency or deference on the implementation of the sanctions, for humanitarian reasons or 'specific economic problems' within specific parameters defined by the Security Council. ${ }^{62}$ But that is it; a Sanctions Committee cannot engage in legal, political or factual assessment on the validity of the sanctions themselves, and the implicit legal determinations attached thereto. Therefore, before the Sanctions Committee, Libya can only present requests relating to the manner or extent of implementation of the sanctions; entertaining challenges to the validity of the sanctions simply falls beyond the mandate of the Sanctions Committee.

The CTC is a curious arrangement, possessing a broader mandate than the Sanctions Committees, but nonetheless curtailed within similar 'managerial' confines of the implementation of Resolutions 1373 (2001) and 1540 (2005). ${ }^{63}$ Unlike the Sanctions Committees, the CTC does not oversee the implementation of a specific enforcement measures on specific actors, but rather works with states and other international actors in promoting legal, policy, and practical measures on terrorism in general. Resolution 1373 instructs states to take steps towards the criminalisation and suppression of financing of terrorism, criminalisation and suppression of support to terrorism, cooperation in information exchange, and legal and criminal matters, while Resolution 1540 deals with the criminalisation and suppression of incitement to terrorism. The task of the CTC is, sim-

60. More on managerialism in international law, see, e.g., M. Koskenniemi, 'International Law: Constitutionalism, Managerialism, and the Ethos of Legal Education', I European Journal of Legal Studies, at 1 (2007); 'The Politics of International Law - 20 Years Later', 20 EJIL 1, at 7-19 (2009).

61. Para. 9, Res. 748.

62. Para. $9(\mathrm{e})(\mathrm{f})$, Res. 748

63. The CTC was established through Res. 1373 in 2001; later, the implementation of Resolution 1540 was entrusted upon the CTC. Since 2004, the work of the CTC is assisted by an Executive Directorate (CTED), see SC Res. 1535 of 26 March 2004. 
ply put, to serve as a nucleus of international cooperation on the above-mentioned objectives: its dealing with states is limited to steering them towards the implementation of the necessary legislative, policy, and practical measures on terrorism in general, and not on specific incidents. This task of the CTC is undertaken through country visits, state-reporting systems, coordination of technical support, compilation and dissemination of best practices, and organisation of special meetings to synchronise the work of multiple international actors. ${ }^{64}$ These different working methods of the CTC are essentially designed to assess and respond to what states are doing in response to Resolutions 1373 and 1540, what they are not doing, what some have done better, and what assistance others may require to implement those better practices. As could be gleaned from these working methods, the essence of the mandate of the CTC is mobilising and assisting states towards the elimination of a shared problem that is terrorism. The grand rule concerning the positioning of states towards each other is cooperation: that all states are to act in solidarity with each other in the face of a universal threat, and the CTC is there to help realise such solidarity, not to entertain inter-state 'squabble' that detracts from momentum. ${ }^{65}$

The CTC's dealings with a state focuses on the activities of that state only and do not lend themselves to the hearing of inter-state complaints; other states would be brought into this equation only to the extent that they offer best practices or assistance in counterterrorism. The experience of some states that tried to use the state reporting system ${ }^{66}$ to voice inter-state complaints illustrates this. For example, in most of its reports on Resolution 1373, Cuba forwarded a list of charges particularly against the US, alleging that the latter harbours Cuba's most wanted terrorists. ${ }^{67}$ Azerbaijan also used its reports to level strong accusations of sponsorship of terrorism against its neighbour Armenia. In Armenia, Azerbaijna claimed, 'terrorism has been raised to the status of state policy'. ${ }^{68}$ Regarding an alleged terrorist group headed by a certain Gaji Mahomedovich

64. Further, see website of the CTC, <http://www.un.org/en/sc/ctc/> (last visited 27 Sep. 2013).

65. Sir Jeremy Greenstock, the first president of the CTC stated unequivocally, in an interview with the BBC on 28 October 2001: 'our job in the Counter Terrorism Committee is to upgrade the legislation and the executive machinery of every state in the UN who is willing but perhaps not so capable of dealing with terrorist finance, a safe haven for terrorism and other actions against terrorism.... the Counter Terrorism Committee is there not to define terrorism but to upgrade the capability of states to deal with it when they find it ... My committee is not going to get into the business of judging who is a terrorist or whether something is a terrorist act ...', available at <http://www.bbc.co.uk/otr/intext/ 20011028_int_3.html> (last visited 27 Sep. 2013)

66. Reports on the implementation of Res. 1373, and later also Res. 1540.

67. See, Letters from the Permanent Representative of Cuba to the United Nations addressed to the Chairman of the Security Council Committee established pursuant to Res. 1373 (2001) concerning counter-terrorism dated 27 December 2001 (S/2002/15), 24 September 2002 (S/2002/1093) and 27 August 2003 (S/2003/838)

68. Letter from the Chargé d'affaires of the Permanent Mission of Azerbaijan to the United Nations addressed to the Chairman of the Security Council Committee established pursuant to resolution 1373 (2001) concerning counter-terrorism, dated 27 December 2001 (S/2001/1325).
Mahomed, Azerbaijan reported to the CTC that the group's operatives had 'undergone training in the territory of the Republic of Armenia' ${ }^{69}$ In both instances, the CTC simply avoided responding to the inter-state accusations. Even after repeated reminders in subsequent reports, the CTC did not respond to those allegations. Whether those allegations were reported out of the need to ventilate frustrations or with serious expectation of redress, the CTC's lack of response fits well with the observation that the CTC system is a mechanism for cooperation and does not entertain inter-state disputes.

It is possible to conclude, therefore, that little meaningful platform for inter-state disputation exists within both the Security Council and its subsidiary bodies: the former offering illusive possibilities and the later avoiding any such pretence altogether.

\section{Summary and Final Remarks}

In the past two decades, and even more so after the terrorist attacks of September 11, 2001, the Security Council has become a more active nucleus of international legal and policy counterterrorism undertakings. This has also meant an increased intervention of the Security Council in inter-state disputes relating to terrorism. Since the 2009 sanctions mentioned at the beginning, the Security Council has subjected Eritrea to additional sanctions $^{70}$ in response to the accusations of Ethiopia and Djibouti that Eritrea sponsors terrorist attacks in their territories. ${ }^{71}$ As the Libya case demonstrates, even if Eritrea was a party to relevant international treaties such as the Terrorist Financing Convention, the Security Council path proves more attractive to Ethiopia and Djibouti, given that Eritrea is already on the 'black list' of powerful members of the Council (the Western P5 states). As opposed to the sense of routine and restraint represented by 'treaty-based dispute settlement', resort to the Security Council is accompanied by a sense of extreme exigency ('international peace and security') that presumably justifies bypassing 'frustrating' treatybased procedures and the taking of swift and strong measures.

69. Letter from the Chargé d'affaires of the Permanent Mission of Azerbaijan to the United Nations addressed to the Chairman of the Security Council Committee established pursuant to resolution 1373 (2001) concerning counter-terrorism, on 31 October 2003 (S/2003/1085).

70. SC Res. 2023, 5 December 2011. These new sanctions targeted the financial sources of the Eritrean government, by imposing restrictions on its lucrative mining sector and prohibiting the collection of so called 'Diaspora tax' from Eritreans living abroad.

71. See, Letter dated 18 January 2012 from the Permanent Representative of Ethiopia to the United Nations addressed to the President of the Security Council, S/2012/44; Verbatim record of the 6674th meeting of the Security Council, agenda 'peace and security in Africa', 5 December 2011, S/PV.6674. These accusations were partly corroborated by reports of the expert team monitoring the implementation of the 2009 sanctions. See, Letter dated 18 July 2011 from the Chairman of the Security Council Committee pursuant to resolutions 751 (1992) and 1907 (2009) concerning Somalia and Eritrea addressed to the President of the Security Council, S/2011/433. 
Resort to the treaty-based dispute-settlement mechanisms such as the ICJ is of little help as the Security Council resolutions prima facie pervade its treaty rights, and if the unlikely judicial review of such resolutions materialises, it provides too little too late. Equally distressing for states in the position of Eritrea is the fact that the Security Council system does not provide an even platform for inter-state disputation. It is admitted that in most disputes, an outcome at the Security Council is the function of the relative political support that the opposing sides garner. The playing field is more decidedly uneven for states such as Eritrea - states that are considered 'reclusive' by the Western P5 members. In relation to the issue of terrorism, 'reclusive' are those states that fall outside the global circle of counterterrorism solidarity, which is embodied and coordinated by the Security Council and spearheaded by the Western (P5) states. States that do not partake in this counterterrorism solidarity find themselves in a difficult position: on the one hand they are urged by the Security Council to become parties to the international treaties on terrorism, and on the other their resort to the dispute-settlement mechanisms of these treaties subverted and rendered inconsequential by the actions of the same Council. An active Security Council in the era of counterterrorism spells lack of peaceful means of disputation for these states as they become trapped between a hostile Security Council and an unhelpful treaty-based mechanism: caught between a rock and a hard place. 